\title{
A Review on Chitosan: Ecofriendly Multiple Potential Applications in the Food Industry
}

\author{
Safaa Abdel-Aleem Mohammad El-Aidie \\ Dairy Technology Department, Animal Production Research Institute, \\ Agricultural Research Centre, Giza, Egypt. \\ Post-Doctoral Fellow, Lincoln University College, Malaysia \\ Correspondence E-mail: gmido55@yahoo.com
}

\begin{abstract}
Recently, increasing attention has been paid to development of new functional materials for the environment and health, due to the huge waste produced annually by the shellfish processing industry and the absence of waste management which lead to environmental and human health negative effects. The extraction of chitin from crustaceans' shells may be a solution to minimize the waste and to produce chitosan, a valuable compound which possess biological properties (e.g., anti-cancer, antioxidant, and immune-enhancing) with application in several fields (e.g., food, medical, pharmaceutical, cosmetic, chemicals, agricultural crops, and textile). On the basis of the results of different studies, chitosan, a natural bio-degradable and non- toxic bio-polysaccharide derived from chitin, has potential to be used as natural antimicrobial. Chitosan has exhibited high antimicrobial activity against a wide variety of pathogenic and spoilage microorganisms, including fungi, Grampositive and Gram negative bacteria. The aim of the present review was to summarize the most important information on chitin and chitosan as ecofriendly materials from its bioactivity point of view and to highlight various aspects such as characteristics with their potential applications especially focusing on the food industry field.
\end{abstract}

Keywords: Shellfish, chitin, chitosan, antimicrobial, antioxidant

\section{Introduction}

Disposal of waste produced annually by the shellfish processing industries exemplify a practical challenge. Whereas, by-products represents with approximately $75 \%$ of the total weight of crustaceans (shrimp, crabs, prawns, lobster, cuttlefish and krill) (Kuddus \& Ahmad, 2013) and often, seafood wastes are thrown away at sea, burned, or left out to spoil (Xu et al., 2013). So, the extraction of chitin from crustaceans' shells and its use as is or after further processing may be a way to minimize the waste and to produce valuable compounds with remarkable biological properties and application in different fields
(Hamed et al., 2016).

Chitosan; a linear polysaccharide consisting of $(1,4)$-linked 2- amino-deoxy- $\beta$-D-glucan, is a deacetylated derivative of chitin and is considered a bio based environmental friendly material, which is the second most abundant polysaccharide found in nature after cellulose and estimated to be produced annually almost as much as 10 billion tons (Peter, 1995; Caner \& Cansiz, 2007; Fernandez-Saiz et al., 2009; Revathi et al., 2012; Du et al., 2014). Chitosan is a highly insoluble material like cellulose in its solubility and low chemical reactivity. It is a white, hard, inelastic, nitrogenous 
polysaccharide. Chitosan is prepared commercially by alkaline deacetylation of chitin obtained from the exoskeletons of marine crustaceans, insects, mushroom, fungi and algae cell walls. Chitosan and its derivatives are renewable, biocompatible, biodegradable, and non-toxic compounds that have many biological activities such as: anti-cancer (Salah et al., 2013), antioxidant (Yen et al., 2008), anti-microbial (Goy et al., 2009), anticoagulant (Vongchan et al., 2003), antihypertensive, antidiabetic, antiobesity, antiallergic, antiinflammatory, neuroprotective and matrix metalloproteinases inhibitory effects ( $\mathrm{Ngo}$ et al., 2015).

Chitosan has a lot of applications in agriculture, coating of seeds for improved yield and protection from fungal diseases (Hirano, 1997; Knorr, 1984; Shahidi et al., 1999), biotechnology processes, in production of cell and enzyme immobilization matrices, healingaccelerating sutures and coverings, contact lenses, and artificial skin (Begin \& Calsteren, 1999), waste water purification (Knorr, 1991), and chelation of metals (Shahidi et al., 1999). Chitosan is used to form gels, films, beads, and fibers (Guibal, 2004; Sankararamakrishnan et al., 2006; Zivanovic et al., 2007), and in medicine as wound dressings (Koide, 1998). Chitosan has been researched for use in the food industry in various fields, including as an antimicrobial, antioxidant, a thickening agent in beverages, a clarifying agent in juices, and as a packaging material (Devlieghere et al., 2004; Shahidi et al., 1999; Xie et al., 2001). The health care industry uses about $65 \%$ of total chitosan, agriculture $12 \%$, waste and water treatments $7 \%$, the food and beverage industry $6 \%$, and immobilization and biotechnology 5\% (Knorr, 1991; Li et al., 1997).

Chitosan is being extensively used in the pharmaceutical industry, paper making, photography, solid state batteries, chromatography, dietary supplements and animal feed (Skjak-Braek et al., 1989; Gupta \& Ravi Kumar, 2000; Uhrich, et al., 1999). Some of research has been conducted to use chitosan as a drug delivery vehicle, especially for the treatment of colon diseases, such as ulcerative colitis and Crohn's disease and as a dietary supplement for lowering cholesterol and controlling overweight (Kumar et al., 2004). Chitosan, as a potential food preservative of natural origin, has been approved by the United States Food and Drug Administration (USFDA) as a Generally Recognized as Safe (GARS) food additive (USFDA, 2013). Therefore, in this article, summarizes the recent studies for the different potential applications of chitosan for improving quality and shelf life of foods.

\section{Chitosan structure and physicochemical characterization}

Chitosan has three types of reactive functional groups; an amino group as well as both primary and secondary hydroxyl groups at the C-2, C-3 and C-6 positions, respectively (Youssef et al., 2015). It is structurally similar to cellulose, but it is an aminopolymer and has acetamide groups at the C-2 positions in place of the hydroxyl groups. The structures of cellulose, chitin and chitosan are shown in Figure1. Cellulose is a homopolymer, while chitin and chitosan are heteropolymers. Chitin and chitosan are of commercial interest due to their high percentage of nitrogen (6.89\%) compared to synthetically substituted cellulose (1.25\%) (Kumar, 2000).

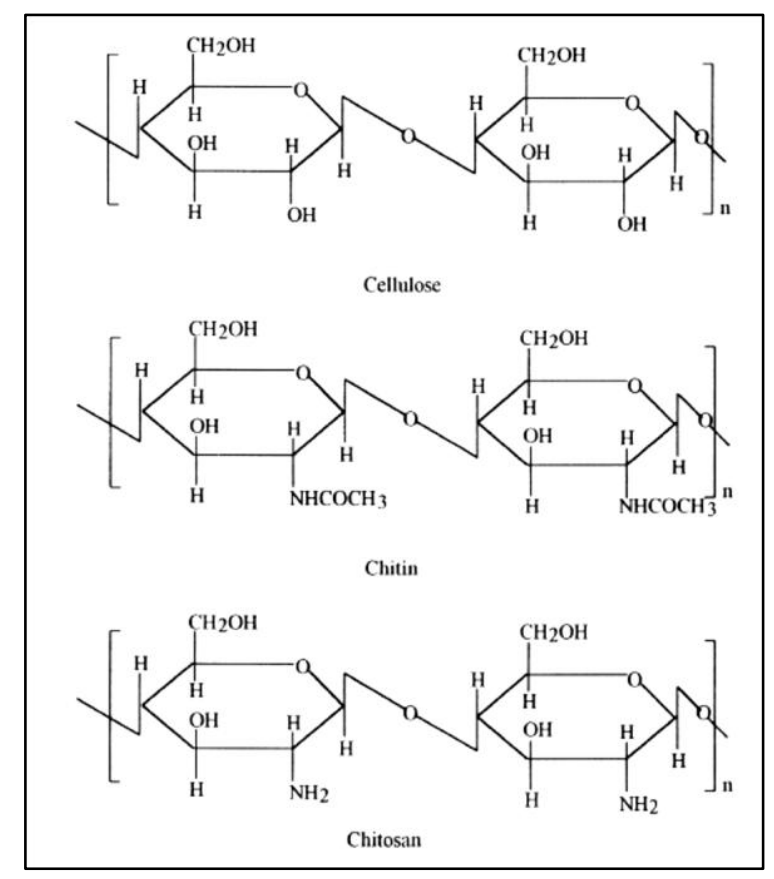

Figure 1: Chemical structure of cellulose, chitin and chitosan 
Chitosan is a high molecular weight cationic linear polysaccharide that contains copolymers of D-glucosamine (deacetylated units) and Nacetyl-D-glucosamine (acetylated units) linked by $\beta(1,4)$ glycosidic bonds. This biopolymer is obtained by the partial deacetylation of chitin. Chitosan is considered to be polycationic, nontoxic, biocompatible, and biodegradable (Zhang et al., 2010; Teng, 2011; Yuan et al., 2011; Anaya et al., 2013; Younes et al., 2014; Reesha et al., 2015; Yuan et al., 2016). The degree of deacetylation is generally defined as the glucosamine/N-acetyl glucosamine ratio, which goes up as chitin is converted to chitosan. Therefore, when the percentage of $\mathrm{N}$-acetyl glucosamine is higher than glucosamine, the biopolymer is called chitin and when the percentage of glucosamine exceeds $\mathrm{N}$-acetyl glucosamine the compound is called chitosan (Khor \& Lim, 2003; Ramírez et al., 2010; Viarsagh et al., 2010). The most important physicochemical characteristics of chitosan are its degree of deacetylation (DDA) and the molecular weight. The DDA has influence on all the physicochemical properties such as molecular weight, viscosity, solubility, etc. This parameter can also influence the solubility of the polymer in organic or aqueous solvents, where by increasing the DDA, the solubility increases. While molecular weight affects antibacterial properties (No et al., 2002; Liu et al., 2006).

Chitin is insoluble in most organic solvents, while chitosan is insoluble at neutral and alkaline $\mathrm{pH}$ in aqueous solution but it is readily soluble in dilute acids $(\mathrm{pH}<6-6.5)$ such as acetic acid, formic acid, succinic acid, lactic acid, and malic acid along with dilute $\mathrm{HCl}$. This is because chitosan can be considered a strong base as it possesses primary amino groups (No et al., 2007; Sogias et al., 2010; Tungtong et al., 2012). The presence the amino groups are highly advantageous, providing distinctive functions and conducting modification reactions. So, chemical modifications of these groups have provided numerous useful materials in different fields of application (Crini \& Badot, 2008; Kablan et al., 2008). At low pH, these amines get protonated and become positively charged and that makes chitosan a water-soluble cationic polyelectrolyte. On the other hand, as the $\mathrm{pH}$ increases above 6, chitosan's amines become deprotonated and the polymer loses its charge and becomes insoluble. This unique property makes it appropriate for a wide range of applications in foods, cosmetics, and pharmaceuticals (Ferraro et al., 2010).

\section{Extraction of Chitin}

There are two types of methods are used to obtain chitin: chemical and biological (microbial) methods (Figure 2). The chemical methods are the most commonly used treatment commercially, although it has several defects such as: uneconomical, ecounfriendly, and negatively, those affect the physico-chemical properties of chitin. Another drawback of chemical chitin purification is that the removed proteins and minerals, although potentially valuable supplements for human foods and animal feeds, are sufficiently damaged that they are no longer appropriate for these applications (Arbia et al., 2013; Hamed et al., 2016). Therefore, the interest in biological extraction is increasing since it is a safer and cheaper treatment for chitin recovery. But till now, it has been limited to laboratory scale studies (Kaur \& Dhillon, 2013).

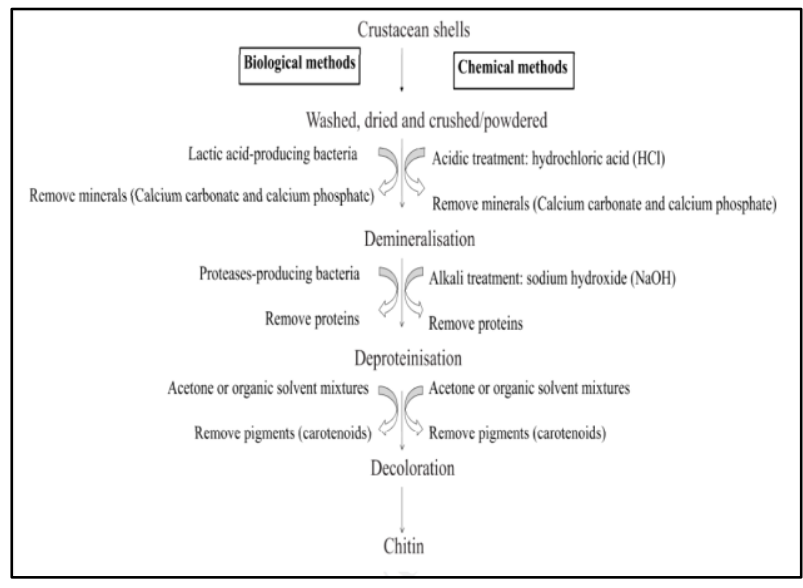

Figure 2: Chitin extraction by chemical and biological methods

\section{Chemical methods}

After obtaining the shells from different sources, they are washed, dried, and grounded into a powder (Abdou et al., 2008). The traditional chemical methods involve three steps: demineralisation, deproteinisation, and decoloration. The first step consists of dissolving the powdered raw material with an 
acidic treatment with hydrochloric acid, the preferred reagent. The purpose is to remove mineral constituents (calcium carbonate and calcium phosphate). Proteins are then extracted from the decalcified shells by treating them with dilute aqueous sodium hydroxide (deproteination); crude chitin is then obtained. A decoloration step is added if a colorless product is wanted. Acetone or an organic solvent mixture is used to remove the pigments such as carotenoids. This yields a partially deacetylated chitin, which may then be further deacetylated to chitosan. This chitin is termed a-chitin because of its crystal structure. Treatment of this chitin with $50 \%$ $\mathrm{NaOH}$ for $1-3 \mathrm{~h}$ at $120^{\circ} \mathrm{C}$ gives a $70 \%$ deacetylated chitin (chitosan), which is soluble in many dilute acids. Repeating this step can give deacetylation values up to $98 \%$ (Abdulkarim et al., 2013; Benhabiles et al., 2012; Mohammed et al., 2013). Chitosan, obtained from the alkaline deacetylation of chitin, is a functional polysaccharide with great potential in food applications and packaging requirements (Fernández-Pan et al., 2015).

\section{Biological methods}

To avoid acidic and alkali treatments that could be a source of environmental problems, biological treatments offer an alternative way to extract chitin from crustacean shells. Lactic acid-producing bacteria have been used for demineralization of crustacean shells. In fact, the lactic acid produced by bacteria reacts with the calcium carbonate component in the biomass waste resulting in the formation of calcium lactate, which can be precipitated and removed by washing (Arbia et al., 2013).

For the deproteinisation, proteases from bacteria will eliminate proteins. The biological treatment consists in a fermentation of the crustacean bio waste by different species of lactic or non-lactic bacteria such as Lactobacillus plantarum, Pseudomonas aeruginosa K-187, Serratia marcescens FS-3, or Bacillus subtilis (Jo et al., 2008). Two other bacteria Bacillus cereus and Exiguobacterium acetylicum have shown high activity with both the deproteinisation and demineralization steps. The fermentation of shrimp shell wastes resulted in 97.1 and $92.8 \%$ deproteinisation, and 95 and $92 \%$ demineralisation, respectively (Sorokulova et al., 2009).

\section{Food applications of chitosan}

Chitin and its derivatives are known to have wide range of biological activities including

antimicrobial effects, antioxidant effects, clarification and de-acidification of fruit juices and antimicrobial edible packaging that could be used in the food industry to improve food safety, quality, and shelf-life.

\section{Antimicrobial activity of chitosan}

Chitosan and its derivatives have attracted attention as a potential food preservative of natural origin due to its antimicrobial activity against a wide range of foodborne filamentous fungi, yeast, and bacteria (Sethulekshmi, 2014; Barikani et al., 2014; Severino et al., 2015; Ali et al., 2015; Yang et al., 2015; Lekjing, 2016). The mechanism of the antimicrobial activity of chitosan and their derivatives has not yet been fully elucidated, but several hypotheses have been proposed. The most feasible hypotheses are a change in cell permeability barrier due to interactions between the positively charged chitosan molecules and the negatively charged microbial cell membranes (Figure 3). This interaction leads to the leakage of proteinaceous and other intracellular constituents (Fang et al., 1994; Chen et al., 1998; No et al., 2007; Xing et al., 2009; Li et al., 2015; Chien et al., 2016).

Chitosan also acts as a chelating agent that selectively binds trace metals and thereby inhibits the production of toxins and microbial growth (Cuero et al., 1991; Li et al., 2010; Chien et al., 2016; Yuan et al., 2016). It also activates several defense processes in the host tissue (El Ghaouth et al., 1992), acts as a water binding agent and inhibits various enzymes (Young et al., 1982). Binding of chitosan with DNA and inhibition of mRNA synthesis occurs via chitosan penetrating the nuclei of the micro-organisms and interfering with the synthesis of mRNA and proteins (Sudharshan et al., 1992; Devlieghere et al., 2004; Chen et al., 2005; El-tahlawy et al., 2005). 


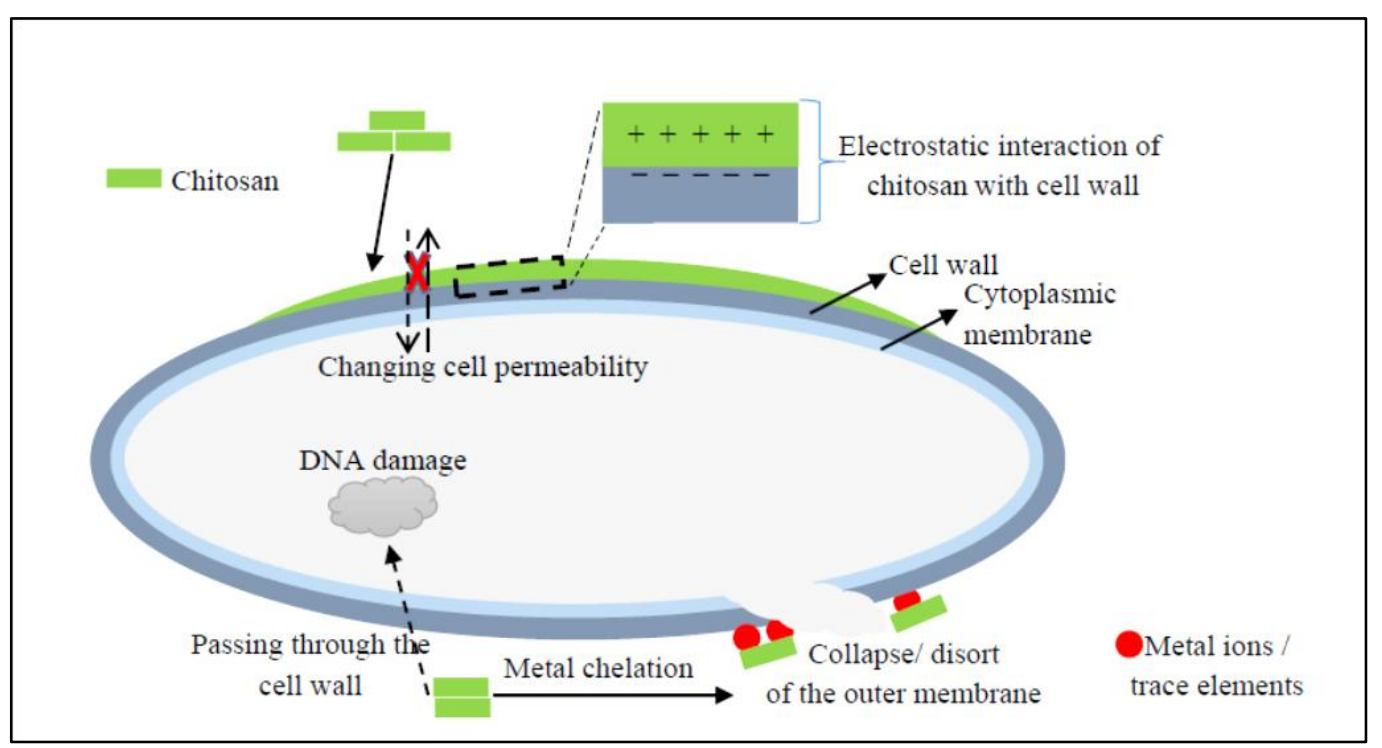

Figure3: Schematic representation of antimicrobial mechanisms of chitosan and its derivatives

Chitosan on the surface of the cell can form a polymer membrane which prevents nutrients from entering the cell (Zheng et al., 2000; Helander et al., 2001; Liu et al., 2004) or acts as an oxygen barrier which can inhibit the growth of aerobic bacteria (Yuan et al., 2016). Chitosan generally has antimicrobial activity against both Gram-positive and Gramnegative bacteria as well as fungi, while it has stronger bactericidal effects against bacteria rather than against fungi (Ziani et al., 2009; Kong et al., 2010).

The antibacterial effects of chitosan and chitosan oligomers are dependent on several factors such as its molecular weight, degree of deacetylation (DD), source, derivatives, $\mathrm{pH}$, concentration, type of microorganism, etc., which should be considered before being applied (Chien et al., 2016; Hosseinnejad \& Jafari 2016). Chitosan has been successfully used to prolong shelf-life of longan fruit, fresh cut broccoli, and raspberry and many other fruits and vegetables (Jiang \& Li, 2001; Moreiraet al., 2011; Tezotto-Uliana et al., 2014). The addition of chitosan to food inhibits microorganisms' growth and avoids poor appearance, off flavors, and economic losses. El-Diasty et al., (2012) noticed that by adding chitosan to cheese it improved its mycological quality. Mould and yeast growth were inhibited and shelf-life was extended. Devlieghere et al., (2004) showed that native chitosan was significantly more active against Candida lambica at $\mathrm{pH} 4.0$ than at $\mathrm{pH} 6.0$. Also, it was demonstrated by Roller and Covill (1999) that inhibitory properties of chitosan against Mucorracemosus were greater at lower $\mathrm{pH}$.

No et al., (2002) revealed that $0.1 \%$ chitosan (MW = 1671, 1106, 746, 470, 224 and $28 \mathrm{kDa}$ ) showed stronger bactericidal effects against grampositive bacteria than gram-negative bacteria. For gram-negative bacteria, chitosan of $746 \mathrm{kDa}$ appeared most effective against $E$. coli and Pseudomonas fluorescens, compared with chitosan $470 \mathrm{kDa}$ against Salmonella Typhimurium and Vibrio parahaemolyticus. Recently, Younes et al., (2014) demonstrated that antibacterial activity was further enhanced for gram-negative bacteria with decreasing MW, whereas, opposite effect was observed with the gram positive bacteria. Concerning the antifungal activity, the influence of chitosan characteristics was dependent on the particular type of fungus.

\section{Antioxidative properties of chitosan}

Reactive oxygen species (ROS) such as $\mathrm{H}_{2} \mathrm{O}_{2}$, hydroxyl radicals, and superoxide lead to oxidative stress which is correlated with various pathologies: cancer (Manda et al., 2009), cardiovascular disease (Zhang et al., 2010), premature aging (Cui et al., 2012), rheumatoid arthritis, and inflammation (Filippin et al., 2008). Chitosan and several of its derivatives, which being safe and non-toxic have shown antioxidant effects (Park \& Kim, 
2010). Thus it could be added as an ingredient for the production of functional food which could prevent age-related and diet-related diseases retarding the progress of numerous chronic diseases (Kerch, 2015).

The oxidation of highly unsaturated food lipids causes off-favors and rancidity. Usually, synthetic antioxidants such as butylated hydroxyl toluene (BHT) and butylated hydroxyl anisole (BHA) are used. However, because of potential health hazards associated with such compounds (Younes \& Rinaudo, 2015), more safe and natural antioxidants have been preferred; especially if a lack of toxicity can be demonstrated (Harish Prashanth \& Tharanathan, 2007).

The addition of $1 \%$ chitosan resulted in a decrease of $70 \%$ in 2-thiobarbituric acid reactive substances (TBARS) values of meat after 3 days of storage at $4^{\circ} \mathrm{C}$. Chitosan's inhibition seems to be related to its chelation of the free iron that is released from the heme proteins of meat during heat processing (Tharanathan \& Kittur, 2003).

The highly unsaturated fatty acids commonly found in seafood are particularly sensitive to oxidative change during storage. This oxidation is catalyzed by the high concentrations of pro-oxidants such as hemoglobin and metal ions in the fish muscle (No et al., 2007). Treatment of herring fish samples with chitosan, however, showed lower peroxide values and total volatile aldehydes than the untreated samples. The antioxidant effect of chitosan depends on its molecular weight, concentration, and viscosity (Kamilet al., 2002). Chitosan with different viscosity were used $(360,57$, and $14 \mathrm{cP})$ to treat the fish samples. The corresponding viscosity average molecular weights were 1.8 $\times 10^{6}, 9.6 \times 10^{5}$, and $6.6 \times 10^{5} \mathrm{Da}$. All three biopolymers showed antioxidant effects, i.e., they lowered peroxide values, TBARS, and total volatile aldehydes. However, the low viscosity chitosan (14 cP) showed the strongest antioxidative effect (Lin \& Chou, 2004). Chitosans may retard lipid oxidation by chelating ferrous ions present in the fish model system, thus eliminating prooxidant activity of ferrous ions or preventing their conversion to ferric ion (No et al., 2007).
Kim \& Thomas (2007) also observed similar results with chitosan with different molecular weights $(30,90$, and $120 \mathrm{kDa})$ in Atlantic salmon (Salmosalar). The antioxidant activity was measured as decreased TBARS and increased 2,2-diphenyl-1-picrylhydrazyl (DPPH) free radical-scavenging activity. The scavenging effect of chitosan was compared to that of BHT and an equivalent efficiency of $85 \%$ was obtained. Moreover, the lowest molecular weight chitosan (30 kDa) showed the highest activity (Hamed et al., 2016).

\section{Clarification and deacidification of fruit juices}

Processing of clarified fruit juices commonly involves the use of clarifying agents, including gelatin, bentonite, silica sol, tannins (Simpson et al., 1994), potassium caseinate and polyvinyl pyrrolidone (Spagna et al., 1996). Chitosan can be used as a clarifying agent due to its polycationic behavior inacidic media since protonated chitosan interacts with negatively compounds through electrostatic interactions. Chitosan has been used as clarifying agent of fruit juices (Chatterjee et al., 2004; Ghorbel-Bellaaj et al., 2012;Cesar et al., 2014), wines (Chagas et al., 2012), beer (Gassara et al., 2015), and tea (Rao et al., 2011). Chitosan salts, which carry astrong positive charge, have been shown to be effective as dehazing agents; they may also be used to control acidity in fruit juices (Imeri and Knorr, 1988). Chitosan is a good clarifying agent for grapefruit juice either with or without pectinase treatment (Spagna et al., 1996) and highly effective fining agent for apple juice, which can afford zero turbidity products with $0.8 \mathrm{~kg} / \mathrm{m}^{3}$ of chitosan (Soto-Perlata et al., 1989). In a similar study, Spagna et al., (1996) observed that chitosan has a good affinity for polyphenolic compounds such as catechins, proanthocyanidins, cinnamic acid and their derivatives that can change the initial strawyellow colour of white wines into deep goldenyellow colour due to their oxidative products. By adding chitosan to grapefruit juice at a concentration of $0.015 \mathrm{~g} / \mathrm{mL}$, total acid content was reduced by about $52.6 \%$ due to decreasing the amount of citric acid, tartaric acid, malic acid, oxalic acid and ascorbic acid, by $56.6,41.2,38.8,36.8$ and $6.5 \%$, 
respectively (Rwan and Wu 1996). MartínDiana et al., (2009) incorporated chitosan in un-pasteurized orange juice and evaluated of quality and nutritional markers. Their results recommend the use of chitosan at concentrations up to $1 \mathrm{~g} \mathrm{~L}^{-1}$ to extend quality and preserve ascorbic acid and carotenoids during storage time of fresh orange juice, thus avoiding the use of standard thermal treatments which produces a negative impact on the nutritional value.

\section{Antimicrobial edible packaging}

Considering the health tendency of the modern food technology, the use of bio-based active films as packaging materials is very important. The antibacterial properties of chitosan have also been used as active edible packaging (Hamed et al., 2016). Biofilms have been formed from chitosan that allow long term storage of food products. Antimicrobial coating of vegetables, fruits, grains, and fish retard microbial invasion as chitosan acts as a protective barrier to enhance the sensory and nutritional quality of the food (Sinha et al., 2014; Aranaz et al., 2009). There are many mechanisms involved in extending shelf life of food by coating films. These include controlled moisture transfer between food and surrounding environment, controlled release of chemical agents like antimicrobial substances, antioxidants, reduction of oxygen partial pressure in the package that results in a decreased rate of metabolism, controlled rate of respiration, high impermeability to certain substances like fats and oils, temperature control, structural reinforcement of food and coat flavor compounds and leavening agents in the form of microcapsules (Shahidi et al., 1999). Besides being a protective barrier, edible biopolymer films can be used as carriers of bioactive compounds to enhancing food quality. Polymeric bioactive films could be combined with different antimicrobial agents such as organic acids, bacteriocins (nisin and lacticin), plant extracts (thymol, p-cymene, and cinnamaldehyde), proteins (e.g., conalbumin), antibiotics, fungicides, and chelating agents (EDTA) to reduce food spoilage by pathogenic microorganisms and enhance shelf-life (Dutta et al., 2012). Chitosan-based edible films are biodegradable and can be consumed along with the product in the package. Moreover, they form transparent films with good mechanical properties that constitute a shell protecting the appearance and the quality of the food inside (Bourbon et al., 2011; Park et al., 2013). A numbers of investigations have shown that pure chitosan coating exhibited antibacterial activity in shrimp during iced or refrigerated storage, refrigerated cod and herring, refrigerated silver carp fillets, refrigerated chicken breast fillets and meat fillets, skinless frankfurters and cooked pork sausages in refrigerated storage (Jeon et al., 2002; Khanjari et al., 2013; Latou et al., 2014; Ramezani et al., 2015; Upadhyay et al., 2015; Wang et al., 2015; Lekjing, 2016). Özdemir \& Gökmen (2017) found that by using coating mixture of $1 \%$ chitosan and $\% 1$ ascorbic acid to pomegranate arils extends its shelf-life by improving microbiological safety, preserving nutritional and sensory quality. Antimicrobial films have been prepared by including various organic acids and essential oils in a chitosan matrix, and the ability of these bio-based films to inhibit the growth of indigenous (lactic acid bacteria and Enterobacteriaceae) or inoculated bacteria (Lactobacillus sakei and Serratia liquefaciens) onto the surfaces of vacuum-packed cured meat products have been investigated (Aider, 2010).

\section{Conclusion}

Chitosan and its derivatives are valuable compounds that meet the needs of consumers for natural products that impact positively on health. Therefore, they can be applied in food industrial applications as natural preservatives or for active packaging due to their antimicrobial and antioxidant properties, allowing extending the shelf-life while decreasing food waste entailing environmental and economic benefits. These positively charged polysaccharides are also useful for many food applications such as beverages clarification and encapsulation of bioactive compounds. Above all, chitosan and its derivatives are eco-friendly. The shellfish processing industries are a large source of byproducts, predominantly chitosan. Despite their potential value, crustacean shell wastes are still underutilized and their use in all of the 
above food applications needs to be further researched. At the same time, the various industries need to be encouraged to incorporate many of these applications

\section{References}

Abdou, E. S., Nagy, K. S. A., \& Elsabee, M. Z. (2008). Extraction and characterization of chitin and chitosan from local sources. Bioresource Technology, 99,1359-1367.

Abdulkarim, A., Isa, M. T., Abdulsalam, S., Muhammad, A. J., \& Ameh, A.O. (2013). Extraction and characterisation of chitin and chitosan from Mussel Shell. Civil and Environmental Research, 3, 108-114.

Aider, M. (2010). Chitosan application for active bio-based films production and potential in the food industry. LWT-Food Science and Technology, 43(6), 837-842.

Ali, A., Noh, N. M., \& Mustafa, M. A. (2015). Antimicrobial activity of chitosan enriched with lemongrass oil against anthracnose of bell pepper. Food Packaging and Shelf Life, 3, 5661.

Anaya, P., Cardenas, G., Lavayen, V., Garcia, A., \& O'Dwyer, C. (2013). Chitosan gel film bandages: correlating structure, composition, and antimicrobial properties. Journal of Applied Polymer Science, 121, 3939-3948.

Aranaz, I., Mengibar, M., Harris, R., Panos, I., Miralles, B., \& Acosta, N. (2009). Functional characterization of chitin and chitosan. Current Chemical Biology, 3, 203-230.

Arbia, W., Arbia, L., Adour, L., \& Amrane, A. (2013). Chitin extraction from crustacean shells using biological methods-a review. Food Technology and Biotechnology 51, 12-25.

Barikani, M., Oliaei, E., Seddiqi, H., \&Honarkar, H. (2014). Preparation and application of chitin and its derivatives: a review. Iranian Polymer Journal, 23, 307-326.

Bégin, A., \& Van Calsteren, M. R. (1999). Antimicrobial films produced from chitosan. International Journal of Biological Macromolecules, 26(1), 63-67.

Benhabiles, M. S., Salah, R., Lounici, H., Drouiche, N., Goosen, M.F.A., \& Mameri, N. commercially due to, their technology readiness level for the majority of the applications are still underutilized.

(2012). Antibacterial activity of chitin, chitosan and its oligomers prepared from shrimp shell waste. Food Hydrocolloids, 29, 48-56.

Bourbon, A. I., Pinheiro, A. C., Cerqueira, M. A., Rocha, C. M., Avides, M. C., Quintas, M.A., \& Vicente, A. A. (2011). Physico-chemical characterization of chitosan-based edible films incorporating bioactive compounds of different molecular weight. Journal of Food Engineering, 106,111-118.

Caner, C., \& Cansiz, O. (2007). Effectiveness of chitosan-based coating in improving shelflife of eggs. Journal of the Science of Food and Agriculture, 87(2), 227-232.

Cesar, L. T., de Freitas Cabral, M., Maia, G. A., de Figueiredo, R. W., de Miranda, M. R. A., de Sousa, P. H. M., \& Gomes, C. L. (2014). Effects of clarification on physicochemical characteristics, antioxidant capacity and quality attributes of açaí (Euterpeoleracea Mart.) juice. Journal of Food Science and Technology, 51(11), 3293-3300.

Chagas, R., Monteiro, S., \& Ferreira, R. B. (2012). Assessment of potential side effects of common fining agents used for white wine protein stabilization. American journal of enology and viticulture, 63, 574-578.

Chatterjee, S., Chatterjee, S., Chatterjee, B. P. \& Guha, A. K. (2004). Clarification of fruit juice with chitosan. Process biochemistry, 39(12), 2229-2232.

Chen, C., Liau, W. \& Tsai, G. (1998). Antibacterial Effects of $\mathrm{N}$-Sulfonated and $\mathrm{N}$ Sulfobenzoyl Chitosan and Application to Oyster Preservation. J. Food Protection 61, 1124- 1128.

Chen, S., Wu, G., \& Zeng, H. (2005). Preparation of high antimicrobial activity thiourea chitosan $\mathrm{Ag}+$ complex. Carbohydrate Polymers, 60, 33-38.

Chien, R. C., Yen, M. T., \& Mau, J. L. (2016). Antimicrobial and antitumor activities of 
chitosan from shiitake stipes, compared to commercial chitosan from crab shells. Carbohydrate polymers, 138, 259-264.

Crini, G., \& Badot, P. M. (2008). Application of chitosan, a natural aminopolysaccharide, for dye removal from aqueous solutions by adsorption processes using batch studies: a review of recent literature. Progress in polymer science, 33(4), 399-447.

Cuero, R. G., Osuji, G., \& Washington, A. (1991). N-carboxymethylchitosan inhibition of aflatoxin production: role of zinc. Biotechnology Letters, 13(6), 441-444.

Cui, H., Kong, Y., \& Zhang, H. (2012). Oxidative stress, mitochondrial dysfunction, and aging. Journal of Signal Transduction, 2012, 1-13. doi: 10.1155/2012/646354.

Devlieghere, F., Vermeulen, A., \& Debevere, J. (2004). Chitosan: antimicrobial activity, interactions with food components and applicability as a coating on fruit and vegetables. Food Microbiology, 21, 703-714.

Du, J., Tan, E., Kim, H. J., Zhang, A., Bhattacharya, R., \& Yarema, K. J. (2014). Carbohydrate polymers. Comparative evaluation of chitosan, cellulose acetate, and polyethersulfonenanofiber scaffolds for neural differentiation. Carbohydrate Polymers, 99, 483-490.

Dutta, J., Tripathi, S., \& Dutta, P. K. (2012). Progress in antimicrobial activities of chitin, chitosan and its oligosaccharides: a systematic study needs for food applications. Food Science and Technology International, 18(1), 3-34.

El-Diasty, E. M., Nesreen, Z., \&Hoda, A. M. (2012). Using of Chitosan as Antifungal Agentin Kariesh Cheese. New York Science Journal, 5, 5-10.

El Ghaouth, A., Arul, J., Asselin, A. \& Benhamou, N. (1992). Antifungal Activity of Chitosan on Post-Harvest Pathogens: Induction of Morphological and Cytological Alterations an Rhizopus stolonifer. Mycol. Res. 96, 769-779.

El-tahlawy, K. F., El-bendary, M. A., Elhendawy, A. G., \& Hudson, S. M. (2005). The antimicrobial activity of cotton fabrics treated with different crosslinking agents and chitosan. Carbohydrate Polymers, 60, 421430.

Fang, S.W., Li, C.F. \& Shih, D.Y.C. (1994). Antifungal Activity of Chitosan and its preservative Effect on Low-Sugar Candied Kumquat. J. Food Protection 56, 136-140.

Fernandez-Saiz, P., Lagaron, J. M., \& Ocio, M. J. (2009). Optimization of the biocide properties of chitosan for its application in the design of active films of interest in the food area. Food Hydrocolloids, 23, 913-921.

Fernández-Pan, I., Maté, J. I., Gardrat, C., \& Coma, V. (2015). Effect of chitosan molecular weight on the antimicrobial activity and release rate of carvacrol - enriched films. Food Hydrocolloids, 51, 60-68.

Ferraro, V., Cruz, I. B., Jorge, R. F., Malcata, F. X., Pintado, M. E., \& Castro, P. M. L. (2010). Valorisation of natural extracts from marine source focused on marine by-products: a review. Food Research International, 43, 2221-2233.

Filippin, L. I., Vercelino, R., Marroni, N. P., \& Xavier, R. M. (2008). Redox signalling and the inflammatory response in rheumatoid arthritis. Clinical \& Experimental Immunology, 152,415422.

Gassara, F., Antzak, C., Ajila, C. M., Sarma, S. J., Brar, S. K., \& Verma, M. (2015). Chitin and chitosan as natural flocculants for beer clarification. Journal of Food Engineering, 166, 80-85.

Ghorbel-Bellaaj, O., Jridi, M., Khaled, H. B., Jellouli, K., \& Nasri, M. (2012). Bioconversion of shrimp shell waste for the production of antioxidant and chitosan used as fruit juice clarifier. International journal of food science \& technology, 47(9), 1835-1841.

Goy, R. C., de Britto, D., \& Assis, O. B. G. (2009). A review of the antimicrobial activity of chitosan. Polimeros, 19, 241-247.

Guibal, E. (2004). Interactions of metal ions with chitosan-based sorbents: a review. Separationand Purification Technology, 38, 43-74.

Gupta, K. C., \& Ravi Kumar, M. N. V. (2000). Drug release behavior of beads and 
microgranules of chitosan. Biomaterials, 21, 1115-1119.

Hamed, I., Özogul, F., \& Regenstein, J. M. (2016). Industrial applications of crustacean by-products (chitin, chitosan, and chitooligosaccharides): A review. Trends in Food Science \& Technology, 48, 40-50.

Harish Prashanth, K. V., \& Tharanathan, R. N. (2007). Chitin / chitosan: modifications and their unlimited application potential-an overview. Trends in Food Science \& Technology, 18, 117-131.

Helander, I. M., Nurmiaho-Lassila, E. L., Ahvenainen, R., Rhoades, J., \& Roller, S. (2001). Chitosan disrupts the barrier properties of the outer membrane of gram-negative bacteria. International Journal of Food Microbiology, 71, 235-244.

Hirano, S. (1997). Application of chitin and chitosan in the ecological an environmental fields.In M. F. A. Goosen (Ed.), Applications of chitin and chitosan (pp. 31e54). Lancaster, PA: Technomic Publishing Co., Inc.

Hosseinnejad, M., \& Jafari, S. M. (2016). Evaluation of different factors affecting antimicrobial properties of chitosan. International Journal of Biological Macromolecules, 85, 467-475.

Imeri, A.G. \& Knorr, D. (1988). Effect of chitosan on yield and compositional data of carrot and apple juice. Journal of Food Science, 53(6), 1707-1709.

Jeon, Y. J., Kamil, J. Y. V. A., \& Shahidi, F. (2002). Chitosan as an edible invisible film for quality preservation of herring and Atlantic cod. Journal of Agricultural and Food Chemistry, 50(18): 5167-5178.

Jiang, Y. M., \& Li, Y. B. (2001). Effects of chitosan coating on postharvest life and quality of longan fruit. Food Chemistry, 73(2), 139143.

Jo, G. H., Jung, W. J., Kuk, J. H., Oh, K. T., Kim, Y. J., \& Park, R. D. (2008). Screening of protease-producing Serratiamarcescens FS-3 and its application to deproteinization of crab shell waste for chitin extraction. Carbohydrate Polymers, 74, 504-508.
Kablan,T., Yue.be Yao, C., Francoise, K. A. \& Mathias, O. K. (2008). Determination and modeling of sorption isotherms of chitosan and chitin. Acta ChimSlov. 55, 677-682.

Kamil, J. Y. V. A., Jeon, Y. J., \& Shahidi, F. (2002). Antioxidative activity of chitosans of different viscosity in cooked comminuted flesh of herring (Clupeaharengus). Food Chemistry, 79, 69-77.

Kaur, S., \& Dhillon, G.S. (2013). Recent trends in biological extraction of chitin from marine shell wastes: A review. Critical Reviews in Biotechnology, 35 (1), 44-61.

Kerch, G. (2015). The Potential of Chitosan and Its Derivatives in Prevention and Treatment of Age-Related Diseases. Marine drugs, 13, 2158-2182.

Khanjari, A., Karabagias, I. K., \& Kontominas, M. G. (2013). Combined effect of N,Ocarboxymethyl chitosan and oregano essential oil to extend shelf life and control Listeria monocytogenes in raw chicken meat fillets. LWT-Food Science and Technology, 53(1), 94-99.

Khor, E. \& Lim, L.Y. (2003). Applications of chitin and chitosan. Biomaterials. 24, 23392349.

Kim, K. W., \& Thomas, R. L. (2007). Antioxidative activity of chitosans with varying molecular weights. Food Chemistry, 101, 308313

Knorr, D. (1984). Use of chitinous polymers in food. Food Technology, 38(1), 85-94, 97.

Knorr, D. (1991). Recovery and utilization of chitin and chitosan in food processing waste management. Food Technology, 45(1), 114122.

Koide, S. S. (1998). Chitin-chitosan: properties, benefits and risks. Nutrition Research, 18, 1091-1101.

Kong, M., Chen, X. G., Xing, K., \& Park, H. J. (2010). Antimicrobial properties of chitosan and mode of action: A state of the art review. International Journal of Food Microbiology, 144 (1), 51-63.

Kuddus, S. M., \& Ahmad, R. I. Z. (2013). Isolation of novel chitinolytic bacteria and 
production optimization of extracellular chitinase. Journal of Genetic Engineering and Biotechnology, 11: 39-46.

Kumar, M. N. R. (2000). A review of chitin and chitosan applications. Reactive and functional polymers, 46(1): 1-27.

Kumar, A. B. V., Gowda, L. R., \& Tharanathan, R. N. (2004). Non-specific depolymerization of chitosan by pronase and characterization of the resultant products. The FEBS Journal, 271(4), 713-723

Latou, E., Mexis, S. F., Badeka, A. V., Kontakos, S., \&Kontominas, M. G. (2014). Combined effect of chitosan and modified atmosphere packaging for shelf life extension of chicken breast fillets. LWT-Food Science and Technology, 55(1), 263-268.

Lekjing, S. (2016).A chitosan-based coating with or without clove oil extends the shelf life ofcooked pork sausages in refrigerated storage. Meat Science, 111, 192-197.

Li, Q., Dunn, E. T., Grandmaison, E. W., \& Goosen, M. F. A. (1997). Application and properties of chitosan. In M. F. A. Goosen (Ed.), Applications of chitin and chitosan (pp. 3-29). Lancaster, PA: Technomic Publishing Co., Inc.

Li, X.-F., Feng, X.-Q., Yang, S., Fu, G.-Q., Wanga, T.-P., \& Su, Z.-X. (2010). Chitosan killsEscherichia coli through damage to be of cell membrane mechanism. Carbohydrate Polymers, 79, 493-499.

Li, Z., Yang, F., Yang, R. (2015). Synthesis and characterization of chitosan derivatives with dualantibacterial functional groups. International Journal of Biological Macromolecules, 75, 378-387.

Lin, H. Y., \& Chou, C. C. (2004). Antioxidative activities of water soluble disaccharides of chitosan derivatives. Food Research International, 37, 883-889.

Liu, H., Du, Y., Wang, X., \& Sun, L. (2004). Chitosan kills bacteria through cell membranedamage. International Journal of Food Microbiology, 95, 147-155.

Liu, N., Chen, X. G., Park, H. J., Liu, C. G., Liu, C. S., Meng, X. H., \& Yu, L. J. (2006). Effect of MW and concentration of chitosan on antibacterial activity of Escherichia coli. Carbohydrate polymers, 64(1), 60-65.

Manda, G., Nechifor, M.T., \&Neagu, T.M. (2009). Reactive oxygen species, cancer and anticancer therapies.Current Chemical Biology, 3, 342-366.

Martín-Diana, A. B., Rico, D., Barat, J. M., \& Barry-Ryan, C. (2009).Orange juices enriched with chitosan: Optimisation for extending the shelf-life. Innovative food science \& emerging technologies, 10(4), 590-600.

Mohammed, M. H., Williams, P. A., \&Tverezovskaya, O. (2013). Extraction 803 of chitin from prawn shells and conversion to low molecular mass chitosan. Food Hydrocolloids, 3, 166-171.

Moreira, M. D., Roura, S. I., \& Ponce, A. (2011). Effectiveness of chitosan edible coatings to improve microbiological and sensory quality of fresh cut broccoli. LWTFood Science and Technology, 44(10), 23352341.

No, H. K., Park, N. Y., Lee, S. H., \& Meyers, S. P. (2002). Antibacterial activity of chitosans and chitosan oligomers with different molecular weights. International Journal of Food Microbiology, 74(1), 65-72.

No, H. K., Meyers, S. P., Prinyawiwatkul, W., \& Xu, Z. (2007). Applications of chitosan forimprovement of quality and shelf life of foods: a review. Journal of Food Science, 72 (5).

Özdemir, K. S., \& Gökmen, V. (2017). Extending the shelf-life of pomegranate arils with chitosan-ascorbic acid coating. LWT-Food Science and Technology, 76, 172-180.

Park, B. K., Kim, \& M. M. (2010). Applications of chitin and its derivatives in biological medicine. International Journal of Molecular Sciences, 11, 5152-5164.

Park, H. J., Byun, Y. J., Kim, Y. T., Whiteside, W. S., \& Bae, H. J. (2013). Processes and applications for edible coating and film materials from agropolymers. In J. H. Han (Ed.), Innovations in Food Packaging (pp.257275). London, UK: Academic Press.

Peter, M. G. (1995). Applications and environmental aspects of chitin and 
chitosan. Journal of Macromolecular Science, Part A: Pure and Applied Chemistry, 32(4), 629-640.

Ramezani, Z., Zarei, M., \& Raminnejad, N. (2015). Comparing the effectiveness of chitosan and nanochitosan coatings on the quality of refrigerated silver carp fillets. Food Control, 51, 43-48.

Ramírez, M. Á., Rodriguez, A. T., Alfonso, L., \& Peniche, C. (2010). Chitin and its derivatives as biopolymers with potential agricultural applications. Biotecnologia Aplicada, 27(4), 270-276.

Rao, L., Hayat, K., Lv, Y., Karangwa, E., Xia, S., Jia, C., Zhong, F. \& Zhang, X. (2011). Effect of ultrafiltration and fining adsorbents on the clarification of green tea. Journal of Food Engineering, 102(4), 321-326.

Reesha, K.V., Kumar Panda, S., Bindu, J., \& Varghese, T. O., (2015). Development and characterization of an LDPE/chitosan composite antimicrobial film for chilled fish storage.International Journal of Biological Macromolecules, 79, 934-942.

Revathi, M., Saravanan, Caner, R., \&Shanmugam, A. (2012). Production and characterization of chitinase from Vibrio species, a head waste of shrimp Metapenaeusdobsonii (Miers,1878) and chitin of SepiellainermisOrbigny, 1848. Advances in Bioscience and Biotechnology, 3, 392-397.

Roller, S., \&Covill, N. (1999). The antifungal properties of chitosan in laboratory media and apple Juice. International Journal of Food Microbiology, 47, 67-77.

Rwan, J. \& Wu, J. (1996). Deacidifcation of Grapefruit Juice with Chitosan. Food Science, Taiwan 23, 509- 519.

Salah, R., Michaud, P., Mati, F., Harrat, Z., Lounici, H., Abdi, N., Drouiche, N., \&Mameri,N. (2013).Anticancer activity of chemically prepared shrimp low molecular weight chitin evaluation with the human monocyte leukaemia cell line, THP1.International Journal of Biological Macromolecules, 52, 333- 339.

Sankararamakrishnan, N., Dixit, A., Iyengar, L., \& Sanghi, R. (2006). Removal of hexavalent chromium using a novel cross linked xanthated chitosan. Bioresource Technology, 97, 2377-2382.

Sethulekshmi, C. (2014). Chitin and its benefits.International Journal of Advanced Research in Biological Sciences, 1, 171-175.

Severino, R., Ferrari, G., Vu, K. D., Donsì, F., Salmieri, S., \&Lacroix, M. (2015). Antimicrobial effects of modified chitosan based coating containing nanoemulsion of essential oils, modified atmosphere packaging and gamma irradiation against Escherichia coli O157:H7 and Salmonella Typhimurium on green beans. Food Control, 50, 215-222.

Shahidi, F., Arachchi, J. K. V., \& Jeon, Y. J. (1999). Food applications of chitin and chitosans. Trends in food science \& technology, 10(2), 37-51.

Simpson, B.K., Gagne, N. \& Simpson, M.V. (1994).Bioprocessing of Chitin and Chitosan' in Fisheries Processing: Bio-technological Applications, (Martin, A.M, ed), pp. 155-173, Chapman and Hall, London, UK

Sinha, S., Chand, S., \&Tripathi, P. (2014). Microbial degradation of chitin waste for production of chitosanase and food related bioactive compounds. Applied Biochemistry and Microbiology, 50, 125-133.

Skjak-Braek, G., Anthonsen, T., \&Sandford, P. A. (1989). Chitin and chitosan: Sources, chemistry, biochemistry, physical properties, and applications. New York, NY: Elsevier Applied Science, 443 pp.

Sogias, I. A., Khutoryanskiy, V. V., \& Williams, A. C. (2010). Exploring the factors affectingthe solubility of chitosan in water. Macromolecular Chemistry and Physics, 211, 426-433.

Sorokulova, I., Krumnow, A., Globa, L., \&Vodyanoy, V. (2009). Efficient decomposition of shrimp shell waste using Bacillus cereus and Exiguobacterium acetylicum. Journal of Industrial Microbiology \& Biotechnology, 36, 1123-1126.

Soto-Perlata, N.V., Muller, H. \& Knorr, D. (1989). Effect of Chitosan Treatments on the Clarity and Color of Apple Juice. J. Food Sci. $54,495-496$ 
Spagna, G., Pifferi, P. G., Rangoni, C., Mattivi, F., Nicolini, G., \& Palmonari, R. (1996).The stabilization of white wines by adsorption of phenolic compounds on chitin and chitosan. Food Research International, 29(34), 241-248.

Sudharshan, N.R., Hoover, D.G. \& Knorr, D. (1992). Anti- bacterial Action of Chitosan. Food Biotechnol. 6, 257- 272.

Teng, D. (2011). From chitin to chitosan. In K. Yao, J. Li, F. Yao, \& Y. Yin (Eds.), Chitosan based hydrogels: functions and application (pp. 2-33). Boca Raton, Florida: CRC Press.

Tezotto-Uliana, J. V., Fargoni, G. P., Geerdink, G. M., \& Kluge, R. A. (2014). Chitosan applications pre- or postharvest prolong raspberry shelf-life quality. Postharvest Biology and Technology, 91, 72-77.

Tharanathan, R. N., \& Kittur, F. S. (2003). Chitin-the undisputed bio-molecule 903 of great potential. Critical Reviews in Food Science and Nutrition, 43, 61-87.

Tungtong, S., Okonogi, S., Chowwanapoonpohn, S., Phutdhawong, W., \& Yotsawimonwat, S. (2012). Solubility, viscosity and rheological properties of water-soluble chitosan derivatives. Maejo International Journal of Science and Technology, 6, 315322.

Uhrich, K. E., Cannizzaro, S. M., Langer, R. S., \& Shakesheff, K. M. (1999). Polymeric systems for controlled drug release. Chemical Reviews, 99, 3181.

Upadhyay, A., Upadhyaya, I., Karumathil, D. P., Yin, H. B., Nair, M. S., Bhattaram, V., Venkitanarayanan, K. (2015). Control of Listeria monocytogenes on skinless frankfurters by coating with phytochemicals. LWT-Food Science and Technology, 63(1), 37-42.

USFDA (US Food and Drug Administration). Center for Food Safety and Applied Nutrition. Office of Premarket Approval. GRAS notices received in 2001. Washington, DC: American Society for Microbiology. Available at http://vm.cfsan.fda.gov Accessed 12.03.14.

Viarsagh, M. S., Janmaleki, M., Falahatpisheh, H. R., \& Masoumi, J. (2010). Chitosan preparation from persian gulf shrimp shells and investigating the effect of time on the degree of deacetylation. Journal of Paramedical Sciences 1(2), 2-7.

Vongchan, P., Sajomsang, W., Kasinrerk, W., Subyen, D., \& Kongtawelert, P. (2003). Anticoagulant activities of the chitosan polysulfate synthesized from marine crab shell by semi-heterogeneous conditions. Science Asia, 29, 115-120.

Wang, Y. B., Liu, L., Zhou, J. R., Ruan, X. M., Lin, J. D., \& Fu, L. L. (2015). Effect of chitosan nanoparticle coatings on the quality changes of postharvest whiteleg shrimp, Litopenaeus vannamei, during storage at $4^{\circ} \mathrm{C}$. Food and Bioprocess Technology, 8(4), 907-915.

Xie, W., Xu, P., \& Liu, Q. (2001).Antioxidant activity of water-soluble chitosan derivatives. Bioorganic \& Medicinal Chemistry Letters, 11. pp.1699-1701.

Xing, K., Chen, X. G., Kong, M., Liu, C. S., Cha, D. S., \& Park, H. J. (2009). Effect of oleoylchitosan nanoparticles as a novel antibacterial dispersion systemon viability, membrane permeability and cell morphology of Escherichia coli and Staphylococcus aureus. Carbohydrate Polymers, 76, 17-22.

Xu, Y., Bajaj, M., Schneider, R., Grage, S. L., Ulrich, A. S., Winter, J., \& Gallert, C. (2013). Transformation of the matrix structure of shrimp shells during bacterial deproteination and demineralization. Microbial Cell Factories, 12, 90.

Yang, H., Zheng, J., Huang, C., Zhao, X., Chen, H., \& Sun, Z. (2015). Effects of combined aqueous chlorine dioxide and chitosan coatings on microbial growth and quality maintenance of fresh-cut bamboo shoots (phyllostachys praecox $f$. prevernalis.) during storage. Food and Bioprocess Technology, 8, 1011-1019

Yen, M. T., Yang, J. H., \& Mau, J. L. (2008).Antioxidant properties of chitosan from crabshells. Carbohydrate Polymers, 74, 840844.

Younes, I., \& Rinaudo, M. (2015). Chitin and Chitosan Preparation from Marine Sources.Structure, Properties and Applications. Marine Drugs, 13, 1133-1174. 
Younes, I., Sellimi, S., Rinaudo, M., Jellouli, K., \& Nasri, M. (2014). Influence of acetylationdegree and molecular weight of homogeneous chitosans on antibacterial and antifungalactivities. International Journal of Food Microbiology, 185, 57-63.

Young, D.H., Kohle, H. \&Kauss, H. (1982). Effect of Chitosan on Membrane Permeability of Suspension Cultured Glycine max and Phaseolus vulgaris Cells. Plant Physiol. 70, 1449-1454

Youssef, A. M., Abou-Yousef, H., El-Sayed, S. M., \& Kamel, S. (2015). Mechanical and antibacterial properties of novel high performance chitosan / nanocomposite films. International journal of biological macromolecules, 76, 25-32.

Yuan, Y., Chesnutt, B. M., Haggard, W. O., \& Bumgardner, J. D. (2011). Deacetylation of chitosan: material characterization and in vitro evaluation via albumin adsorption and preosteoblastic cell cultures. Materials, 4(1), 3991416.

Yuan, G. F., Zhang, X. J., Tang, W. Y., \& Sun, H. Y. (2016). Effect of chitosan coating combined with green tea extract on the melanosis and quality of Pacific white shrimp during storage in ice. Cyta-Journal of Food, 14(1), 35-40.
Yuan, G., Lv, H., Tang, W., Zhang, X., \& Sun, $H$. (2016). Effect of chitosan coating combinedwith pomegranate peel extract on the quality of Pacific white shrimp during iced storage. Food Control, 59, 818-823.

Zhang, J., Xia, W., Liu, P., Cheng, Q., Tahirou, T., Gu, W., \& Li, B. (2010). Chitosanmodification and pharmaceutical /biomedical applications. Marine Drugs, 8, 1962-1987.

Zheng, L.-Y., Zhu, J.-F., \& Sun, K.-S. (2000). Antimicrobial activity of chitosan. Materials Science and Engineering, 18, 22-24.

Ziani, K., Fernandez-Pan, I., Royo, M., \& Mate, J. I. (2009). Antifungal activity of films and solutions based on chitosan against typical seed fungi. Food Hydrocolloids, 23, 2309-2314.

Zivanovic, S., Li, J., Davidson, P. M., \& Kit, K. (2007). Physical, mechanical and antimicrobial properties of chitosan / PEO blend films. Biomacromolecules, 8(5), 1505-1510. 